\title{
IMPROVING WAREHOUSE PERFORMANCE IN LOGISTICS COMPANIES IN VIET NAM
}

\author{
Nguyen Thi Van $\mathrm{Ha}^{1 *}$ \\ ${ }^{1}$ University of Transport and Communication
}

\begin{abstract}
Warehouse operation has played an important roles in many logistics companies. Purposes of this research are to analyze current situation of warehouse operation, measure warehouse performance in logistics companies in Viet Nam, and suggest some solutions for their improvement. This study develops measurement scale of warehouse performance based on literature review. This study is mainly implemented based on quanlitative research methodology through conducting case study to explore research objectives. The results indicated that logistics companies in Viet Nam have paid more attention to warehouse operations and tried to improve their performance with different level and awareness. The analysis may make contribution to improving awareness of logistics companies in providing and improving warehouse services in supply chain. These findings support logistics companies in Vietnam to understand more about the ways to improve warehouse operation and performance in logistics companies in Vietnam.
\end{abstract}

Keywords: Warehouse Operation, Warehouse Performance, Logistics Companies

\section{Introduction}

Warehouses are an essential component of any supply chain. Their major roles include: buffering the material flow along the supply chain to accommodate variability caused by factors such as product seasonality and/or batching in production and transportation; consolidation of products from various suppliers for combined delivery to customers; and value-added-processing such as kitting, pricing, labeling, and product customization (Hackman \& J.Bartholdi, 2008). Warehouses are a key aspect of modern supply chains and play a vital role in the success, or failure, of businesses today (Baker \& Canessa, 2007)

Market competition requires continuous improvement in the design and operation of production-distribution networks, which in turn requires higher performance from warehouses (Koster, 2008). The adoption of new management philosophies such as Just-In-Time (JIT) or lean production also brings new challenges for warehouse systems, including tighter inventory control, shorter response time, and a greater product variety. On the other hand, the widespread implementation of new information technologies (IT), such as bar coding, radio frequency communications (RF), and warehouse management systems (WMS), provides new opportunities to improve warehouse operations ( $\mathrm{Gu}$, Goetschalckx, \& Mcginnis, 2010). These opportunities include, but are not limited to: real-time control of warehouse operation, easy communication with the other parts of the supply chain, and high levels of automation (Johnson \& Ginnis, 2011).

Performance studies are a measure of analyzing the performance business in order to benmark against the competition and explore the possibility to improve in order to gain competitive advantage (Johnson \& Ginnis, 2011). Warehousing function is very critical within any supply chain. If the products do not move seamlessly within supply chain business would face serious service related challenges. Therefore, it is necessary to drive performance of the warehouse through the key performance indicators. The warehouse operation are unlike production as they are not repletitive, but a number of measures can be devised to help measure warehouse productitivity (Gu et al., 2010). 
Warehouse performance measures are very critical for providing managers with a clear vision of potential issues and opportunities for improvements. Metrics are tied directly to the business strategy and operation's success drives the financial reults of the organization. If warehouses are going to contribute to be a source for adding value to the supply chain then they need to measure their performance with perfect metrics. Key objectives in designing warehouse operations include increasing productivity, reducing cycle time and increasing accuracy (Chow, Lun, Lee, \& Lau, 2006). Literature has shown that cost and space pressures outweigh the pressures to improve operations because of rising customer demands for faster and more tailored fulfillment. The best performing companies are foucsed on winning in both these dimenstions by creating faster throughput and more workflow agility in their warehouses, they are able to satisfy customer demands (Gu, Goet, \& F.McGinnis, 2016).

According to literature review, the metrics for measuring performance in a warehouse fall into three main categories which includes: order fulfillment, inventory management and labor productivity. The various metrics for measuring the performance is as shown in Table 1.

Table 1: Various metrics for measuring the performance of warehouse

\begin{tabular}{|c|c|c|c|}
\hline Category & Measure Metrics & Definition & $\begin{array}{l}\text { How to measure and unit to } \\
\text { measure }\end{array}$ \\
\hline \multirow{5}{*}{$\begin{array}{l}\text { Order } \\
\text { Fufillment }\end{array}$} & On time delivery & $\begin{array}{l}\text { Oders delivered on time per } \\
\text { customer requested date }\end{array}$ & $\begin{array}{l}\text { Percentage of orders delivered on } \\
\text { time per year }\end{array}$ \\
\hline & Order fill rate & $\begin{array}{l}\text { Orders filled completely on } \\
\text { first shipment }\end{array}$ & $\begin{array}{l}\text { Percentage of orders filled } \\
\text { completely on first shipment }\end{array}$ \\
\hline & Line accuracy & $\begin{array}{l}\text { Lines picked, packed and ship } \\
\text { perfectly }\end{array}$ & $\begin{array}{l}\text { Percentages of lins picked, } \\
\text { packed, and shipped perfectly }\end{array}$ \\
\hline & Order cycle time & $\begin{array}{l}\text { Time from order placement to } \\
\text { shipment }\end{array}$ & $\begin{array}{l}\text { Average time from order } \\
\text { placement to shipment }\end{array}$ \\
\hline & $\begin{array}{l}\text { Perfect order } \\
\text { completion }\end{array}$ & $\begin{array}{l}\text { Orders delivered without } \\
\text { changes, damage, or invoice } \\
\text { errors }\end{array}$ & $\begin{array}{l}\text { Percentage of orders delivered } \\
\text { without changes, damage or } \\
\text { invoice errors }\end{array}$ \\
\hline \multirow{5}{*}{$\begin{array}{l}\text { Inventory } \\
\text { management } \\
\text { measures }\end{array}$} & Inventory accucacy & $\begin{array}{l}\text { Actual inventory quantity to } \\
\text { system-reported quantity }\end{array}$ & $\begin{array}{l}\text { Percentages of the gap between } \\
\text { them }\end{array}$ \\
\hline & Damaged inventory & $\begin{array}{l}\text { Damage measure as } \% \text { of } \\
\text { inventory value }\end{array}$ & Percentage of inventory value \\
\hline & Storage utilization & $\begin{array}{l}\text { Occupied space (square } \\
\text { footage) as a } \% \text { of storage } \\
\text { capacity (square footage) }\end{array}$ & $\begin{array}{l}\text { Occupied space (square footage) } \\
\text { as a } \% \text { of storage capacity } \\
\text { (square footage) }\end{array}$ \\
\hline & Dock to stock time & $\begin{array}{l}\text { Average time from carrier } \\
\text { arrival until product is availble } \\
\text { for order picking }\end{array}$ & $\begin{array}{l}\text { Average time (hours or minutes) } \\
\text { from carrier arrival until product } \\
\text { is availble for order picking }\end{array}$ \\
\hline & Inventory visibility & $\begin{array}{l}\text { Time from physical receipt to } \\
\text { customer service notice of } \\
\text { availability }\end{array}$ & $\begin{array}{l}\text { Time from physical receipt to } \\
\text { customer service notice of } \\
\text { availability }\end{array}$ \\
\hline \multirow{3}{*}{$\begin{array}{l}\text { Warehouse } \\
\text { productivity }\end{array}$} & Oders per hour & $\begin{array}{l}\text { Average number of orders } \\
\text { picked and packed per person - } \\
\text { hour }\end{array}$ & $\begin{array}{l}\text { Average number of orders picked } \\
\text { and packed per person - hour }\end{array}$ \\
\hline & Lines per hour & $\begin{array}{l}\text { Average number of orders lines } \\
\text { picked and packed per person - } \\
\text { hour }\end{array}$ & $\begin{array}{l}\text { Average number of orders lines } \\
\text { picked and packed per person - } \\
\text { hour }\end{array}$ \\
\hline & Items per hours & $\begin{array}{l}\text { Average numbers of orders } \\
\text { items picked and packed per } \\
\text { person - hour }\end{array}$ & $\begin{array}{l}\text { Average numbers of orders items } \\
\text { picked and packed per person - } \\
\text { hour }\end{array}$ \\
\hline
\end{tabular}




\begin{tabular}{|l|l|l|l|}
\hline Category & Measure Metrics & Definition & $\begin{array}{l}\text { How to measure and unit to } \\
\text { measure }\end{array}$ \\
\hline & Cost per hours & $\begin{array}{l}\text { Total warehousing costs - } \\
\text { Fixed: space, utilities and and } \\
\text { depreciation; Variable: } \\
\text { labor/supplies }\end{array}$ & $\begin{array}{l}\text { Total warehousing costs - Fixed: } \\
\text { space, utilities and and } \\
\text { depreciation; Variable: } \\
\text { labor/supplies }\end{array}$ \\
\cline { 2 - 4 } & Cost per order & $\begin{array}{l}\text { Total wareshousing cost as a } \\
\text { percent of total company sales }\end{array}$ & $\begin{array}{l}\text { Total wareshousing cost as a } \\
\text { percent of total company sales }\end{array}$ \\
\hline
\end{tabular}

The next parts include some contents related to research methodology and design; research findings related to actual situation of measuring warehouse performance in some companies; suggesting solutions, conclusions and recommendations.

\section{Research Methodology}

Research design follows quanlitative research methodology. Quanlitative research was carried out through conducting observations, understanding and analyzing case study based on information collected. All data was scanned, tested and analyzed to show current warehouse and wareshouse managment system in some logistics companies.

In order to analyze practices of warehouse performance in logistics companies in Vietnam, the study used an exploratory research approach by collecting primary and secondary information such as reviewing available literature, conducting four case studies of logistics companies in Viet Nam, implementing informal interviews, direct observations and site visit. The generation of data comes from a number of sources to ensure the validity of analysis. Content analysis is used for secondary literature and primary data is collected through case study, site visit and observations

We conducted in-depth interviews with four companies to have a deeper analysis of awareness and practical application of warehouse operation and performance in logistics companies in Viet Nam. Interview guides were developed with different open questions and answers. After getting answers from four main case studies, the author coded main contents, gave evaluation marks for them, calculated total marks for all of them, and ranked them to use for analyzing.

General information about four companies is presented in Table 2 for an overview of business orientation and main activities. Due to some reasons of trade secrecy and requirements of companies to be interviewed, so the name of the company will be encoded in the order of A, B, C, and D. All of them are full 3PLPs located in North and South of Viet Nam.

Overall, all four companies interviewed responded that they have their own warehouse and run warehouse management system with the different level and support of various equipment and machine. 
Table 2: Information about four logistics companies for conducting case studies

\begin{tabular}{|c|c|}
\hline Company Code & Description \\
\hline Company A & $\begin{array}{l}\text { This company has the largest logistics center in Vietnam with a total warehouse area of over } \\
100,000 \mathrm{~m} 2 \text {. In which the distribution center No. } 1 \text { area of } 8,800 \mathrm{~m} 2 \text {, the distribution center No. } 2 \\
\text { area of more than } 24,000 \mathrm{~m} 2 \text {, the capacity of } 60,000 \text { pallets (equivalent to } 90,000 \text { CBM), dotting in } \\
\text { dynamic economic centers as HCMC, Binh Duong, Hanoi, Hai phong. The centers are equipped } \\
\text { with state-of-the-art management technologies such as Infor's warehouse management (WMS) } \\
\text { software, Business Intelligence (BI), EDI inventory. International standards such as FM Global, } \\
\text { Green (Green Initiative), HACCP (for food), C-TPAT, TAPA .... }\end{array}$ \\
\hline Company B & $\begin{array}{l}\text { It is one of leading providers of aviation logistics services, warehousing and other logistics services } \\
\text { in Vietnam. With the vision "to become the pioneer provider of international standard aviation } \\
\text { logistics services in Vietnam", this companies has been constantly researching, investing and } \\
\text { developing the off-airport cargo terminal system, warehouse system, value-added services and } \\
\text { training activities, developing qualified and dedicated personnel to improve the efficiency of its } \\
\text { supply chain services, bringing the optimal value-added services to customers. }\end{array}$ \\
\hline Company C & $\begin{array}{l}\text { This company is one of leading global logistics service provider in Vietnam that is able to meet } \\
\text { every customer's needs. They provide complete logistics solutions from inland transportation, } \\
\text { ocean shipping and air freight to warehousing, distribution and customs services. With more than } \\
30 \text { years of experience in the field of freight forwarding combined with modern infrastructure, } \\
\text { cutting-edge technology and professional services enable them to provide an efficient supply chain } \\
\text { to all customers. }\end{array}$ \\
\hline Company D & $\begin{array}{l}\text { The main fields of this company are Sea Freight, Trucking, Business Warehouse operators; Cargo } \\
\text { handling, container repair,... This constantly strengthens the organization apparatus, trains and } \\
\text { develops human resources, standardizes service procedures, improves quality of transport systems } \\
\text { and container, provides high quality services by international standards. This company tries to meet } \\
\text { the requirements of optimization services on time, safe goods and reasonable prices from local and } \\
\text { foreign customers. It also attracts capital investments to meet the interests of shareholders, raises } \\
\text { incomes for workers and maintains their company growing and sustainable. }\end{array}$ \\
\hline
\end{tabular}

Research objects are 3PLPs companies with diverse forms of warehouse operation and performance. There are a couple of reasons for choosing these firms. Firstly, they have provided various types of warehouse services including storage, bonded wareshouse, cold warehouse, and added services. Secondly, sizes of warehouse businesses of these companies ranging from medium to large based on the number of employees and the amount of business working capital. Thirdly, their applications of IT for warehouse management system have been evaluated rather good, which made it easy to track data and assess warehouse performance. Fourthly, investing in warehouses/distribution centers and applying IT in managing warehouse has currently been the trend of logistics in Vietnam.

\section{Results and Discussions}

\section{To profile the coverage, the density and the scale of these companies warehouse}

Using the secondary resource from these companies and primary data from indepth interviews through conducting case studies. The author profiles the coverage, the service packages and the scale of these companies'warehouse though Table 3.

These companies have been providing their clients with services of warehouse renting and services package in warehoues. Almost of them have operated their warehouse with different types including CFS warehouse, bonded warehouse, cold/cool warehouse, and distribution center. They are operating warehouse and distribution 
centers in different areas in Vietnam with the total area of more than 100.000 sqm, dotting in dynamic economic centers in Vietnam as HCMC, Da Nang, Hanoi, Hai phong.

\begin{tabular}{|l|l|l|l|l|}
\hline Features & & & \\
\hline Warehouse services & $\mathrm{X}$ & $\mathrm{X}$ & $\mathrm{X}$ & $\mathrm{X}$ \\
\hline Renting Warehouses & $\mathrm{X}$ & $\mathrm{X}$ & $\mathrm{X}$ & $\mathrm{X}$ \\
\hline Types of warehouse & & & $\mathrm{X}$ & $\mathrm{X}$ \\
\hline+ CFS warehouse & $\mathrm{X}$ & $\mathrm{X}$ & $\mathrm{X}$ & $\mathrm{X}$ \\
\hline+ Freezed warehouse & $\mathrm{X}$ & $\mathrm{X}$ & $\mathrm{X}$ & $\mathrm{X}$ \\
\hline+ Bonded warehouse & $\mathrm{X}$ & $\mathrm{X}$ & $\mathrm{X}$ & \\
\hline+ Distribution center & $\mathrm{X}$ & $\mathrm{X}$ & $\mathrm{X}$ \\
\hline+ Others $(. .)$. & $\mathrm{Cold}$ Chain DC & Document storage, & 100.000 & 230.000 \\
\hline Warehouse area $\left(\mathrm{m}^{2}\right)$ & 300.000 & 150.000 & & \\
\hline
\end{tabular}

Table 3: Warehouse Profile of companies interviewed and observed

\section{Awareness of four companies related to warehouse operations and performance}

In order to analyze the situation of warehouse operations and performance, the author assessed four companies' awareness related to warehouse management, strategy and performance as shown in Table 4.

Table 4: Awareness of warehouse management and performance

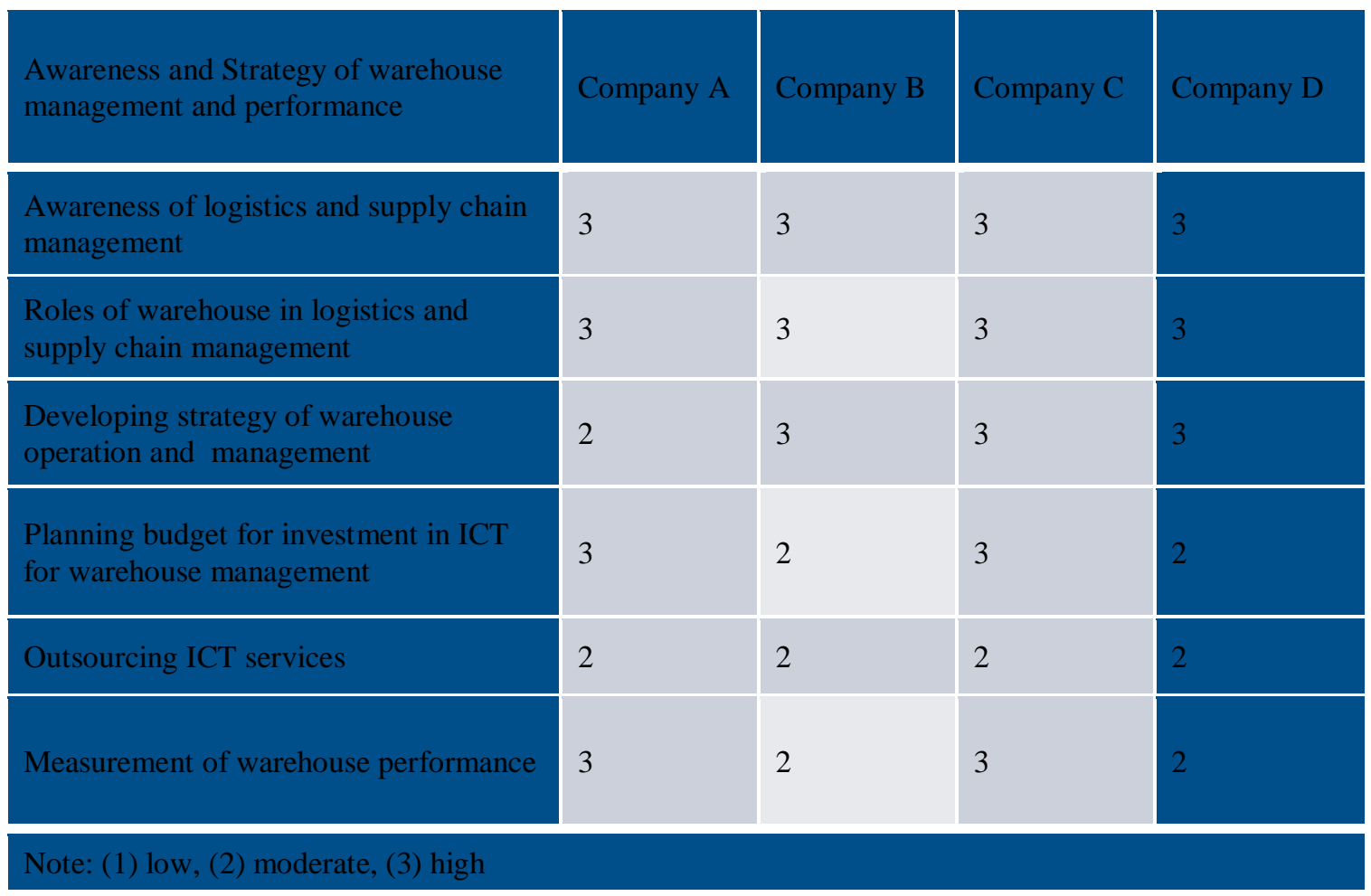


All four companies have high awareness of logistics and supply chain management in offering their services, so they have tried their best effort to provide clients with integrated services of warehouse, transport and additonal services, even port services. Among their business ares, warehouse services have played an important and key role in their business. All of four companies evaluated this viewpoint with highest level. For developing strategy of warehouse operation and management, all of them have integrated their strategy into their overall business strategies' companies because warehouse business services combined with transport services and other additional services have brought them business competitive advantages of providing all-in logistics services, such as: warehousing facility, licensed bonded warehouse storage, customs clearance procedures from all ports/airport, consultation for customs regulations, global logistics, inland transportation, insurance of goods, order fulfillment services, packaging/ repackaging of goods, door to door service.

Almost of four companies have directed to have an excellent warehousing capability to handle customer cargo. Therfore, they have planned planning budget for investment in ICT for warehouse management. For example in case of company A and company $\mathrm{C}$, they invested in big and modern warehouse system in Vietnam equiped with WMS software of Infor, Business Intelligence, State-of-the-art EDI...Moreover, all warehouse are built with ventilation system, humidity and temperature control, supervising cameras..to satisfy international modern standards as FM Global, Green standard, HACCP, C-TPAT, TAPA...Three of four companies, they have developed and built ICT software and technology for warehouse management by their internal IT staff (Company A, C, and D). However almost of them have also outsourced 20-30\% services of ICT for business and warehouse management.

Warehouse performance evaluation has been explored in different ways by four respondents companies. Some of them focus on one specific area while others try to cover all warehouse activities. The performance measurement is commonly assessed by the use of indicators, present in the majority of works. However, for this results, the author showed a common indicators which are used to measure warehouse performance in almost companies interviewed. In these companies, they used two related but distinct approaches to performance measurement: economic (i.e., revenue related to cost) and technical (i.e., outputs related to inputs). The author used only technical indidators for evaluating warehouse perforemance of these companies because economic performance assessment is somewhat difficult (HIGHJUMP, 2016). Warehouses typically do not generate revenues; rather, their function is to support the supply chain including bricks-and-mortar and web-based outlets. Moreover, since a firm's warehouses can be sited in urban, rural, or international locales, the differences in the settings will have a major impact on the costs of the resources used by each warehouse, such as labor and building space (Faber, Koster, \& Smidts, 2017). Furthermore, the acquisition costs of capital equipment specific to warehouses vary depending on general economic conditions and the buying power of the specific warehouse owner (e.g., large 3PL versus start-up company). For these and other reasons, technical measures based on output generated and resources consumed tend to give a clearer picture of operational performance when assessingwarehouses across a group ofwarehouses because themeasures avoid the uncertainty or variation introduced when using financial measures directly (Johnson \& Ginnis, 2011)

\section{Evaluating warehouse performance related to order fulfiment, inventory management measures, and warehouse productivity}

In order to access warehouse performance, the author contacted these companies for asking them about some criteria related to order fulfimment, inventory management meaures and warehouse productivity. The author asked them many related criteria, only some of them are provided becasue of data security related to their commitment with customers. Table 5 showed the common criterial used for four companies in the results of interviews: 
Table 5: Performance measurement of warehouse operation in logistics companies

\begin{tabular}{|l|l|l|l|l|}
\hline $\begin{array}{l}\text { Warehouse Performance } \\
\text { Measurement }\end{array}$ & Company A & Company B & Company C & Company D \\
\hline On time delivery/shipments & $98 \%$ & $96 \%$ & $97 \%$ & $95.87 \%$ \\
\hline Order fill rate & $99 \%$ & $98 \%$ & $97 \%$ & $96 \%$ \\
\hline Order picking accuracy & $99 \%$ & $98 \%$ & $99 \%$ & $98.5 \%$ \\
\hline Perfect order completion & $97 \%$ & $95 \%$ & $98 \%$ & $96 \%$ \\
\hline $\begin{array}{l}\text { Damaged inventory } \\
\text { Storage utilization } \\
\text { (warehouse capacity used) }\end{array}$ & $0.014 \%$ & $0.020 \%$ & $0.015 \%$ & $0.022 \%$ \\
\hline
\end{tabular}

The author asked four respondents companies about the percentage of orders shipped at the planned time, meaning off the dock and in transit to final destination. Almost of the companies have the high level with more than $95 \%$ of shipments on time, especially for the case of company A (98\%) and company C (97\%). However, best-in-class operations ship more than $99.87 \%$ of shipments on time. So all four logistics companies should pay attention more solution of delivering on time for warehouse operation.

Percentage of orders filled completely on first shipment is the second indicator that the author requested these companies to define for their warehouse performance. This work of warehouse in four companies are also well done (more than 96\%) with the support of modern equipment and machine, especially with the applications of ICT for warehouse operation. Company A and Company B get the highest point for this indicator, showing rather good performance of order fill rate.
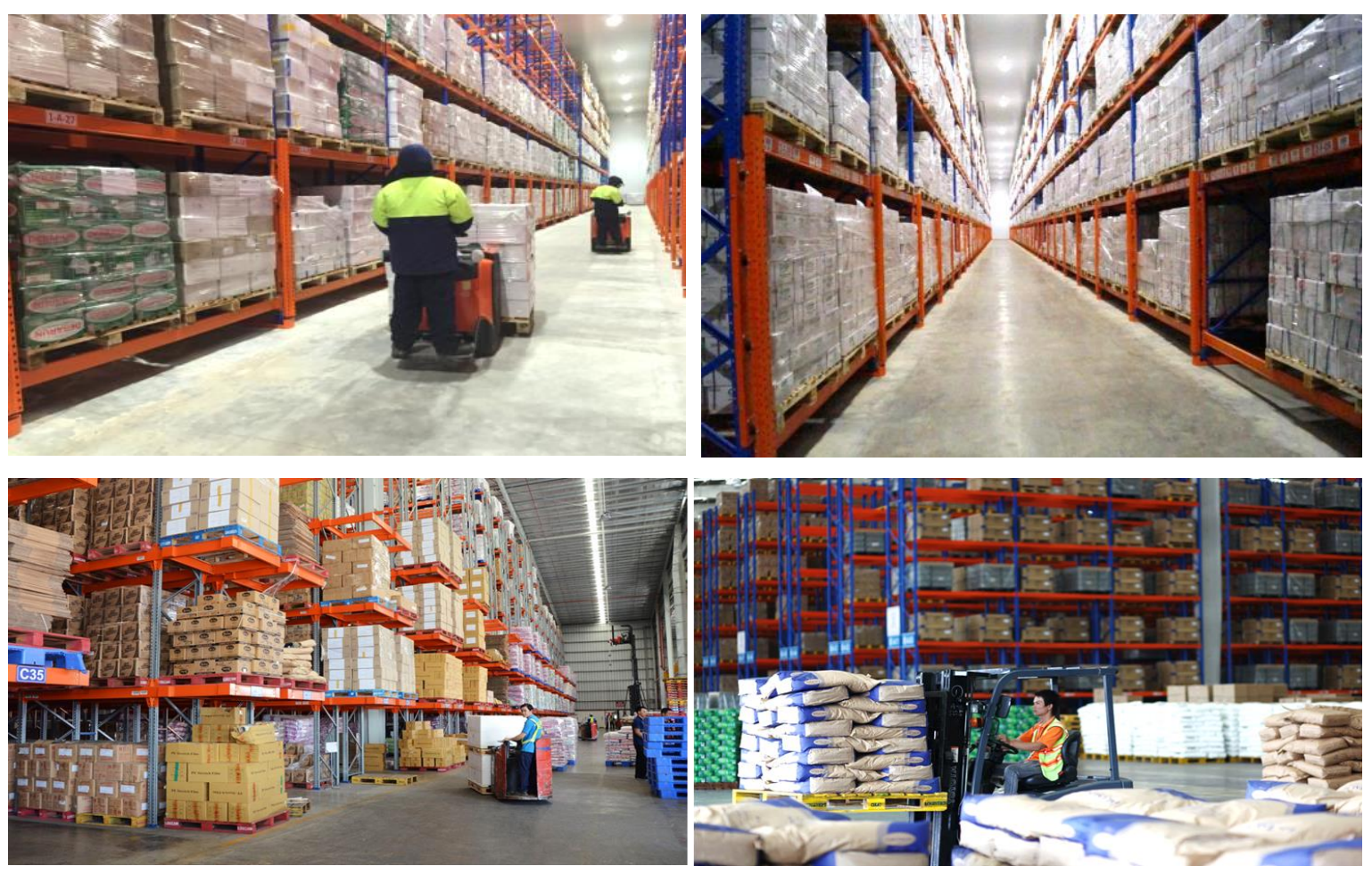
Figure 1: Highly efficient warehouse operation of Company A

Order picking accuracy measures the accuracy of the order picking process against errors caught prior to shipment, such as during packaging. Best-in-class operations pick at more than $99.84 \%$ accuracy. For these companies, the best one is company A and company C. With 99\% accurarcy because these companies have advanced level of applying modern machine and equipment as well as ICT better than other companies. Others two companies (Company B and Company D) should think about improving methods of picking order accurately.

Perfect order completion measure percentage of orders delivered without changes, damage, or invoice errors. During the time of delivyering order out of warehouse, sometimes there are some errors related to changes of requirements from customers, damages due to movement, administrative errors in invoices and packinglists.

Damaged inventory is the measurement of damage measured as $\%$ of inventory value. Normally it is calculated by each customers and upon product category. In this study the author calculated based on the average damaged inventory of all product inventory in their warehouse. The percentage of damaged inventory in all four companies has been still low and still been in permitted limitation (1\%). Among them the company B has the highest damaged inventory with $0.022 \%$. Company A has still got the lowest damaged inventory with only $0.014 \%$ due to their efficient opearation warehouse management system.

In four companies, the author also collected data related to warehouse operation in comparison with their capacity and with the previous year. For example, in case of company C, the performance of CFS warehouse cannot meet the target plan of 2017 and lower than the results of 2016 nearly $51 \%$. The performance of bonded warehouse also obtained the lower results for import in comparison with 2017's target plan (69\%) and the actual implementation of 2016 (74\%). For export, the results of 2017 was better than the import bonded warehouse with the equivalent data of $96 \%$ and $84 \%$. The over-capacity of warehouse operation in company $\mathrm{C}$ related to cold storage warehouse and distribution center.

Table 6: Operation of CFS warehouse, cold storage and bonded warehouse Company C

+ CFS Warhouse $\left(\mathbf{M}^{3}\right)$
\begin{tabular}{|c|c|c|c|c|}
\hline $\begin{array}{c}\text { Plan of } \\
2017\end{array}$ & $\begin{array}{c}\text { Performance } \\
\text { of } 2017\end{array}$ & $\begin{array}{c}\text { Performance } \\
\text { of } 2016\end{array}$ & \multicolumn{2}{|c|}{$\begin{array}{c}(\%) \text { Performance of } \\
2017 \text { compared with }\end{array}$} \\
\cline { 4 - 5 } & & Plan 2017 & $\begin{array}{c}\text { Result } \\
2016\end{array}$ \\
\hline 364,000 & 195,212 & 400,173 & $54 \%$ & $49 \%$ \\
\hline
\end{tabular}

Cold Storage ( Tons)

\begin{tabular}{|c|c|c|c|c|}
\hline \multirow{2}{*}{$\begin{array}{l}\text { Plan of } \\
2017\end{array}$} & \multirow{2}{*}{$\begin{array}{l}\text { Performance } \\
\text { of } 2017\end{array}$} & \multirow{2}{*}{$\begin{array}{l}\text { Performance } \\
\text { of } 2016 \\
\text { Plan } 2017\end{array}$} & \multicolumn{2}{|c|}{$\begin{array}{l}\text { (\%) Performance of } \\
2017 \text { compared with }\end{array}$} \\
\hline & & & $\begin{array}{l}\text { Plan } \\
2017 \\
\end{array}$ & $\begin{array}{l}\text { Result } \\
2016 \\
\end{array}$ \\
\hline 109,500 & 132,859 & 37,467 & $121 \%$ & $355 \%$ \\
\hline
\end{tabular}

+ Bonded Warehouses

Import $\left(M^{3}\right)$

\begin{tabular}{|c|c|c|c|c|}
\hline \multirow{2}{*}{$\begin{array}{l}\text { Plan of } \\
2017\end{array}$} & \multirow{2}{*}{$\begin{array}{l}\text { Performance } \\
\text { of } 2017\end{array}$} & \multirow{2}{*}{$\begin{array}{l}\text { Performance } \\
\text { of } 2016 \\
\text { Plan } 2017\end{array}$} & \multicolumn{2}{|c|}{$\begin{array}{l}(\%) \text { Performance of } \\
2017 \text { compared with }\end{array}$} \\
\hline & & & Plan 2017 & $\begin{array}{c}\text { Result } \\
2016 \\
\end{array}$ \\
\hline 75,142 & 51,803 & 69,767 & $69 \%$ & $74 \%$ \\
\hline
\end{tabular}

\begin{tabular}{|c|c|c|c|c|}
\hline \multicolumn{5}{|c|}{$\operatorname{Export}\left(M^{3}\right)$} \\
\hline \multirow{2}{*}{$\begin{array}{l}\text { Plan of } \\
2017\end{array}$} & \multirow{2}{*}{$\begin{array}{l}\text { Performance } \\
\text { of } 2017\end{array}$} & \multirow{2}{*}{$\begin{array}{l}\text { Performance } \\
\text { of } 2016 \\
\text { Plan } 2017\end{array}$} & \multicolumn{2}{|c|}{$\begin{array}{l}\text { (\%) Performance of } \\
2017 \text { compared wit }\end{array}$} \\
\hline & & & $\begin{array}{l}\text { Plan } \\
2017 \\
\end{array}$ & $\begin{array}{c}\text { Result } \\
2016 \\
\end{array}$ \\
\hline 50,683 & 48,500 & 57,995 & $96 \%$ & $84 \%$ \\
\hline
\end{tabular}

The performance cold warehouse was over the target plan of 2017 (121\%) and the actual implementation of 2016 (355\%), indicating that the demand for cold storage in Vietnam has been increasingly due to more export of seafood and agricultural products. Moreover, the demand for distribution center for processing and fulfiment of input and output products has been also increasing. The clients have nowadays have required logistics companies to provided them with more integrated logistics services. Table 7 shows the operation of distribution center for input and output performance. 
Table 7: Operation of Distribution Center at Company C

Input (Tons)
\begin{tabular}{|c|c|c|c|c|}
\hline Plan of & Performance & Performance & \multicolumn{2}{c|}{$(\%)$ Performance of } \\
of 2016 \\
\cline { 4 - 5 } & 2017 & 2017 & compared with \\
\cline { 4 - 5 } & & Plan 2017 & Plan 2017 & $\begin{array}{c}\text { Result } \\
2016\end{array}$ \\
\hline 167,790 & 246,726 & 145,699 & $147 \%$ & $169 \%$ \\
\hline
\end{tabular}

Output (Tons)
\begin{tabular}{|c|c|c|c|c|}
\hline Plan of & Performance & Performance & \multicolumn{2}{|c|}{$\begin{array}{c}\text { (\%) Performance of } \\
\text { of } 2016\end{array}$} \\
\cline { 4 - 5 } 2017 & of 2017 & Plan 2017 & Plan 2017 & $\begin{array}{c}\text { Result } \\
2016\end{array}$ \\
\hline 165,914 & 250,889 & 137,676 & $151 \%$ & $182 \%$ \\
\hline
\end{tabular}

The applications of ICT and modern machine as well as warehouse management system have supported all four companies to improve their warehouse operation and performance. For example in the case of company D, after six months applying updated WMS, ICT tools, and modern machine \& equipment, the operation of warehouse has been improved with good performance such as better inventory accuracy (99.8\%), on time in full delivery (99.5\%), the $15 \%$ increase of warehouse productivity, and the $10 \%$ reduction of warehouse operation costs.

\section{Conclusions and Recommendations}

The author used quantitative research methods with in-depth interviews to explore the performance of warehouse operation in logistics companies. Almost companies are moving to higher level of performance with more updated applications of warehouse management system and modern technical equipment. The trend of applying IT and upgrading machine and equipment with more information sharing and integration with clients and supplier has been highly accepted to develop by almost of the respondent companies. The finding indicate that logistics companies in Viet Nam have been moving forward in providing their clients with fully integrated logistics services such as transport, warehouse, handling, customs clearance, freight forwarding, document services, and added value services.

With the changes of business environment and mindset, 3PLS providers have paid more attention to identifying possible opportunities of developing, formalizing their strategic decisions of warehouse investment. They have increasingly concerned in sharing information and resources beyond arm's length contract or frame contract to strategic collaboration with their investors to upgratde and improve warehouse performance. They solved the issues related to low warehouse performance through applications and operations of new warehouse management system, information technologies, and modern machine.

Logistics companies in Viet Nam should take a proactive role in the planning, implementation, and evaluation of warehouse operation and performance in both economic and technical indicators. They should pay attention to developing strategy of warehouse investment and ICT applications. For advising, they should understand and apply 9 golden rules for improving warehouse operations and performance: (1) Proper storage solutions are the first step towards keeping a warehouse organized; (2) Upgrading and investing more in modern and automatic machine (Ergonomic Equipment); (3) Applying Principles "Three Rs": reduce, reuse and recycle; (4) Training safety education for warehouse staff and labor; (5) Setting up an effective warehouse management system for increased productivity and better real-time inventory control; (6) Understanding the type of commodity and optimizing the warehouse storage area accordingly; (7). Maintaining good team morale and prompt, quality order fulfillment, which will back up your sales process, especially if you're an online business; (8) Building warehouse performance metrics and implementing strictly the measurement; (9) Always looking at implementing new procedures and looking at new technologies in the market to save both time and effort in daily warehouse operations

With highly complicated supply chain management, e.g. many stakeholders, many processes, and a lot of activities of supply chain, logistics companies should select an appropriate strategy that optimal exploits both internal and external resources for developing and improving warehouse performance. Integrating both internal 
and external resources and capabilities for logistics companies may be the best solution for firms in practices to reduce costs and obtain higher performance

\section{References}

Baker, P., \& Canessa, M. (2007). Warehouse design : A structured approach. European Journal of Operation Researchn, 1-12. https://doi.org/10.1016/j.ejor.2007.11.045

Chow, H. K. H., Lun, K., Lee, W. B., \& Lau, K. C. (2006). Design of a RFID case-based resource management system for warehouse operations. Expert Systems with Applications, 30, 561-576. https://doi.org/10.1016/j.eswa.2005.07.023

Faber, N., Koster, R. B. M. De, \& Smidts, A. (2017). Survival of the fittest: the impact of fit between warehouse management structure and warehouse context on warehouse performance. International Journal of Production Research, 7543(November), 1-20. https://doi.org/10.1080/00207543.2017.1395489

Gu, J., Goet, M., \& F.McGinnis, L. (2016). Research on warehouse operation: A comprehensive review. European Journal of Operation Research, 177(1), 1-21. https://doi.org/10.1016/j.ejor.2006.02.025

Gu, J., Goetschalckx, M., \& Mcginnis, L. F. (2010). Research on warehouse design and performance evaluation: A comprehensive review. European Journal of Operational Research, 203(3), 539-549. https://doi.org/10.1016/j.ejor.2009.07.031

Hackman, S. T., \& J.Bartholdi, J. (2008). Warehouse and Distribution Science. Atlanta.

HIGHJUMP. (2016). IDEAS FOR IMPROVING WAREHOUSE.

Johnson, A., \& Ginnis, L. M. C. (2011). Performance measurement in the warehousing industry. IIE Transaction, 43, 220-230. https://doi.org/10.1080/0740817X.2010.491497

Koster, M. B. M. de. (2008). Benchmarking and Monitoring International Warehouse Operations in Europe. Production and Operation Management, 17(2), 175-183. https://doi.org/10.3401/poms.1080.0013 